\title{
The U.S. Flow of Funds Accounts and Their Uses
}

Albert M. Teplin, of the Board's Division of Research and Statistics, prepared this article. Andrew M. Tyler assisted with the data.

Each day, a wealth of data on household, corporate, and government finances becomes available. The greatest challenge posed by these data is in interpreting the information they contain - that is, in evaluating the information's import in a historical context and determining its usefulness and appropriate weight in forecasting the direction of the U.S. economy. By assembling much of this information into a comprehensive, coherent data set, the U.S. flow of funds accounts produced at the Federal Reserve Board provide a framework in which incoming economic and financial data can be viewed.

In simple terms, the flow of funds accounts measure financial flows across sectors of the economy, tracking funds as they move from those sectors that serve as sources of capital, through intermediaries (such as banks, mutual funds, and pension funds), to sectors that use the capital to acquire physical and financial assets. With data extending back more than half a century, the accounts provide a broadly consistent set of time-series data for measuring financial flows in the economy.

The accounts are useful in documenting central economic trends. They show, for example, the growth of debt for each sector; changes in the sources of credit to households, businesses, and governments; and the development of new financial instruments for providing credit. They document the growth of important economic institutions, such as mutual funds and defined contribution pension plans, and show how these institutions have become woven into the financial fabric of the economy.

Data in the accounts are critical for understanding macroeconomic behavior. They have, for example, been used in recent studies of the wealth effectthe effect of changes in households' net worth on their decisions about saving and consumption. The accounts provide the commonly used time-series measure of overall household wealth, give detail on the composition of that wealth, and shed light on the factors underlying changes in composition, such as increases in the value of equity shares. In related analyses, the accounts have been used to study personal saving. They show how saving is allocated across broad classes of financial and tangible assets and provide alternative measures of personal saving that can be analyzed in conjunction with the measure commonly reported in the national income and product accounts compiled by the Department of Commerce. The accounts have also been used in analyses of business investment and of the implications of business sector leverage for the macroeconomy.

The accounts are used for monetary policy purposes. An economic forecast that integrates the flow of funds accounts with other macroeconomic accounts provides an opportunity to quantify the effects of likely changes in credit conditions on the growth of real activity. A flow of funds forecast also adds a check on the consistency of other elements of an economic forecast, because balance sheet conditions and access to credit and other external funds can be factors underlying the spending and production decisions of households, businesses, and governments.

The comprehensive framework of the flow of funds accounts is useful for interpreting current economic data. ${ }^{1}$ As fragments of information on financial flows become available, they can be evaluated in light of the expectations embedded in the broader flow of funds forecast. Such evaluations may be especially helpful in interpreting the implications of higher frequency data on segments of the financial markets, such as particular types of financial intermediaries or financial instruments.

This article gives a brief overview of the flow of funds accounts and their uses. The next section describes the accounts, offering new users a brief tour of their organization and manner of publication. The two subsequent sections illustrate the uses of the data in the accounts in interpreting the behavior of households and nonfinancial corporate businesses; each

1. A description of such use is given in Susan Hume McIntosh, Jennifer M. Scherschel, and Albert M. Teplin, "Use of the Flow of Funds Accounts for Policymaking at the Federal Reserve," paper presented at the Seminar on Central Bank Uses of Financial Accounts, Frankfurt, Germany, November 22, 1999. 
section begins with a review of the growth of debt within the sector and then moves to a discussion of the determinants of that growth and its implications for economic behavior.

\section{OVERVIEW OF THE ACCOUNTS}

The flow of funds accounts record the acquisition of tangible and financial assets (and the incurrence of liabilities) throughout the U.S. economy and document the sources of funds used to acquire those assets. They also measure the value of assets and liabilities at the end of each quarter. ${ }^{\text {? }}$

\section{Organization}

The accounts trace transactions in more than forty types of financial instruments, such as time and savings deposits, mortgages, corporate bonds, equity shares, mutual fund shares, and bank loans. By recording the net volume of transactions in these instruments, the accounts make it possible to analyze the development of the instruments over time as alternative or complementary vehicles for financing economic activity. They also provide a means of tracking the role of financial intermediaries, such as banks and pension funds, in transferring funds from sectors that have positive saving to those that borrow funds.

Financial transactions are recorded within thirty economic sectors-nonfinancial sectors (households and nonprofit organizations, unincorporated and incorporated businesses, the federal government, state and local governments, and the rest of the world) and financial sectors (commercial banks,

2. A complete description of the accounts is available in Board of Governors of the Federal Reserve System, Guide to the Flow of Funds Accounts (Board of Governors, 2000). insurance companies, pension funds, and other kinds of intermediaries).

Although the basic structure of the flow of funds accounts has remained stable over the half-century they have been prepared, the details have been modified somewhat as sources, procedures, and terminology have changed over time. The accounts also have been modified to increase their accuracy and their usefulness for policymaking and research.

\section{Construction}

The principle underlying the flow of funds accounts is that total sources of funds must equal total uses of funds. That is, all funds supplied by sectors in the economy become uses of funds by sectors. Equality between sources and uses holds within each sector as well as across the entire economy.

Sources of funds are both internal (funds saved from current production) and external (funds raised outside the sector). For the household sector, for example, internal funds are saving from personal disposable income and external funds are funds obtained through borrowing from financial institutions (table 1). Nonfinancial businesses generate internal funds from profits - technically, after-tax profits not distributed to shareholders - and also have available allowances for depreciation of tangible assets; their external funds include debt and equity raised in credit markets and loans from commercial banks, finance companies, and other sources. The internal funds of commercial banks (and of most other financial intermediaries) are similar to those of nonfinancial businesses, but their external funds are typically quite different: Those sources are predominantly deposits, such as checkable accounts and small time deposits, and also include managed liabilities, such as large time deposits.

Sectors use funds to purchase tangible and financial assets. Households, for example, purchase such tangible assets as homes and automobiles and such

1. Sources of funds, selected sectors

\begin{tabular}{|c|c|c|}
\hline Sector & Internal funds & External funds \\
\hline Households & $\begin{array}{l}\text { Personal saving (disposable personal income } \\
\text { less consumption) }\end{array}$ & Loans from banks and other financial intermediaries \\
\hline Nonfinancial businesses & $\begin{array}{l}\text { Undistributed profits (total profits less dividends and taxes); } \\
\text { depreciation allowances }\end{array}$ & $\begin{array}{l}\text { Net issuance of equity; loans from intermediaries and debt } \\
\text { raised in capital markets; direct investment by foreigners } \\
\text { ("rest of the world" sector) }\end{array}$ \\
\hline Banks & $\begin{array}{l}\text { Undistributed profits (total profits less dividends and taxes); } \\
\text { depreciation allowances }\end{array}$ & $\begin{array}{l}\text { Net issuance of equity; checkable deposits; time and } \\
\text { savings deposits; large time deposits }\end{array}$ \\
\hline
\end{tabular}


financial assets as deposits at financial intermediaries, government securities, equity shares, mutual fund shares, and pension fund reserves (table 2). Nonfinancial businesses and banks invest in similar types of tangible assets-real estate, equipment, and software-but in different types of financial assets: Nonfinancial businesses invest in short-term cashequivalent assets, such as deposits and money market funds, and in foreign businesses (foreign direct investment); banks also invest abroad, but domestically they invest mostly in securities and in the loans and mortgages they originate.

The flow of funds accounts trace the sources and uses of funds for each sector and by each instrument, with particular attention to external sources of funds and financial uses of funds. Transactions are recorded as net purchases (or net sales) at the current market (transaction) price. Therefore, exchanges within a sector-for example, the sale of equities by one household and the corresponding purchase by another household - cancel each other out and do not show up in the accounts. Transactions between sectors, on the other hand-such as the sale of equities by a household to a mutual fund-are recorded as a negative value for the sector selling the instrument and a positive value for the sector purchasing the instrument.

The accounts also record the level (or "value outstanding") of financial assets held, and liabilities owed, by sector. The level is generally the sum of net purchases over time. However, for some instruments - particularly equities and other instruments whose value largely reflects equities-the value outstanding is affected by change in the prices of assets. For these instruments, the level at the end of a period for a sector is the accumulation of net purchases plus any appreciation or depreciation resulting from the change in prices.

\section{Data}

The data in the flow funds accounts are maintained as time series. Because work on the accounts has been going on for some time, the historical record for many series is lengthy. Published annual data extend back to 1945 , quarterly data to 1952 , and monthly data for the primary components of domestic nonfinancial debt (the debt of governments, households, and nonfinancial businesses) to 1955 .

Data in the accounts come from many sources; little information is collected specifically for inclusion in the accounts. Among the sources are regulatory reports (such as those submitted by banks and security brokers to supervisory agencies); aggregated data from tax filings (notably, for information on businesses and pension funds); surveys conducted by the Federal Reserve System (for information on the assets and liabilities of households and finance companies); other federal agencies, such as the Department of the Treasury (for information on federal finances and international capital flows), the Department of Commerce (for foreign direct investment statistics, national income and product account data, and other business and government data), and the Department of Agriculture (for information on the farm sector); and nongovernmental entities (such as trade associations, rating agencies, and news services). ${ }^{3}$

Dependence on outside providers means that data are not always in the form or detail needed for the accounts. Moreover, information on some sectors and some types of transactions is available only annually or with a long lag. In both cases, the value of missing items is estimated. Data revisions are incorporated in the accounts as they become available from providers.

Maintaining data series over time also presents a challenge. Over the years, much source material has been discontinued, necessitating the development of new sources and adjustment for breaks in definition or coverage. Also, changes in the financial system have required the incorporation of new financial instruments and institutions in the accounts. And the

3. Detailed information on sources is available in Guide to the Flow of Funds Accounts and in Susan Hume McIntosh, "Financial Accounts in the United States," mimeo prepared for the Group of Financial Statisticians Financial Accounts Seminar, Paris, May 1995.

\section{Uses of funds, selected sectors}

\begin{tabular}{|c|c|c|}
\hline Sector & Tangible assets & Financial assets \\
\hline Households & Owner-occupied homes and other real estate; automobiles & $\begin{array}{l}\text { Deposits; federal government securities; equity shares; } \\
\text { mutual fund shares; pension fund reserves }\end{array}$ \\
\hline Nonfinancial businesses & Real estate; equipment; software & $\begin{array}{l}\text { Deposits; money market mutual funds; direct investment } \\
\text { in foreign businesses }\end{array}$ \\
\hline Banks & Real estate; equipment; software & $\begin{array}{l}\text { Treasury and federal agency securities; loans to households } \\
\text { and businesses; mortgage loans for all types of property }\end{array}$ \\
\hline
\end{tabular}


needs of policy analysis and research have resulted in the inclusion of greater detail and supplementary information.

\section{Publication}

The flow of funds accounts are published quarterly, as a set of tables, in the Federal Reserve's Z.1 statistical release, "Flow of Funds Accounts of the United States." " Data for a new quarter and revisions to data for previous quarters are published about ten weeks after the end of a quarter.

The Z.1 release contains a separate table for each sector and instrument, in both flow and level forms, as well as summary tables for borrowing, debt outstanding, and debt growth, by sector; credit market borrowing and lending, by instrument; and the relation of total liabilities to total financial assets. It also contains balance sheets and level-flow reconciliation tables for the household and nonprofit organizations sector and the domestic nonfarm nonfinancial corporate business sector. Finally, the Z.1 release contains a table that consolidates information for federal, state, and local governments; supplementary tables giving detail on the financial activity of nonprofit organizations, private defined benefit and defined contribution pension funds, and individual retirement accounts; and matrices showing flows and levels for sectors and instruments for the latest complete year.

\section{Relationship to Other Systems of Accounts}

The flow of funds accounts complement-and are linked to-other broad statistical descriptions of the U.S. economy, such as the national income and product accounts and the balance of payments accounts produced by the Department of Commerce. Indeed, the three sets of accounts make up an integrated set of macroeconomic accounts that describe the U.S. economy for policymakers, analysts, and others who desire a comprehensive but compact set of information on the economy's performance. Internationally, countries have been working to harmonize the definitions and accounting conventions used in their national accounts. ${ }^{5}$ Such harmonization will enable

4. The Z.1 statistical release is available in printed form and on the Board's public web site at http://www.federalreserve.gov/releases/ Z1/.

5. The System of National Accounts, published in 1993 (SNA93), is an internationally agreed upon set of definitions and standards for preparing macroeconomic accounts. The flow of funds accounts provide the information for the financial accounts within this set of accounts and serve as a basis for sector balance statements. analysts to compare key economic measures across countries and to study the relationship between economic structure and performance. ${ }^{6}$

\section{HOUSEHOLD SECTOR FINANCES}

The recent rapid rise in household sector debt has received considerable attention. ${ }^{7}$ Some observers have expressed concern that the accumulation of debt may result in widespread financial distress for both borrowers and lenders. However, debt is only one dimension of household finances; the increase in household sector debt is most appropriately viewed within the context of changes in overall household sector wealth.

\section{Debt}

The flow of funds accounts document the substantial rise in household sector debt. By the end of the first quarter of 2001, households had accumulated $\$ 7.2$ trillion in debt, about double the amount they owed at the beginning of the economic expansion in early 1991. Despite a slowing of economic growth this year, household debt has continued to increase rapidly, rising at an annual rate of $73 / 4$ percent in the first quarter, only slightly slower than the average rate for the past three years.

The rise has been apparent for both major types of household debt. Home mortgage debt (debt on owner-occupied homes, including home equity loans) - by far the largest component of household sector liabilities, accounting for 70 percent of household debt at the end of 2000-rose 98 percent from early 1991 through the first quarter of 2001. The other major component, consumer creditcomprising revolving credit (largely credit card debt)

6. A survey of international practices indicates that twenty-three of the twenty-nine countries that are members of the Organisation for Economic Co-operation and Development compile national financial accounts or a subset of the financial accounts. All the compiling countries have implemented or are in the process of implementing SNA93 (or its European counterpart, ESA95) in their national statistics. Ayse Bertrand, "Main Features of Financial Accounts in OECD Countries," Financial Market Trends, no. 76 (June 2000), pp. 149-76.

7. In the flow of funds accounts, the household sector includes nonprofit organizations as well as individuals and families. Separate estimates, also published in the accounts, indicate that nonprofit organizations have in recent years accounted for 5 percent to 7 percent of the assets and liabilities of the combined sector. Because figures for nonprofit organizations are available only annually, and with a considerable lag, and because they lack the necessary detail, analysis is generally carried out for the combined sector. For simplicity, the sector is referred to here as the household sector. 
and nonrevolving credit (auto loans, for example)also about doubled.

No doubt some households have become overburdened with debt. However, the flow of funds accounts indicate that household sector debt has been rising over most of the postwar period. Although the rate of growth has waxed and waned with the business cycle, the amount of debt outstanding has marched upward. Even when household debt is scaled by disposable personal income (after-tax income) to account for population increase, price changes, and the substantial increase in the volume of economic activity over the period, the historical rise in household sector debt has been impressive. Households now owe a little more than one dollar for each dollar of disposable income (chart 1). Ten years ago, they owed about eighty cents for each dollar, and in the early $1950 \mathrm{~s}$ about thirty-five cents. Thus, the recent growth of debt could be viewed as a continuation of a long-term trend.

Research provides scant evidence of a simple or direct link between higher levels of debt relative to income and changes in consumer spending. The lack of a direct relationship may reflect in part the fact that the sustained rise in debt has not necessarily been associated with an increase in the burden of carrying debt, that the use of debt instruments for conducting transactions has been increasing, and that households have been using debt to access the pent-up value of their tangible and financial assets.

For some types of debt, longer loan maturities have made it possible to hold higher outstanding amounts without increasing the servicing burden. Although longer maturities increase total interest expense over time, they also lower periodic payments for a given amount of debt. Auto loan maturities at finance companies now average fifty-five months at origination, compared with forty-five months in the early $1980 \mathrm{~s}$ and thirty-five months in the early 1970 s. Home mortgage originations show a similar, albeit less pronounced, increase in average loan maturity.

Other loan terms that have lowered households' costs of carrying mortgage debt include variable interest rate provisions and flexible down-payment requirements. Although such "nonstandard" terms change the repayment risks for lenders, they also likely broaden the pool of eligible borrowers and enable borrowers who would qualify for a loan under standard terms to carry larger outstanding balances. In fact, home mortgage debt may have risen in part simply because such terms allow a greater proportion of the population to own rather than rent their homes. Census Bureau data indicate that home ownership
1. Household sector debt relative to disposable personal income, 1952-2001:Q1

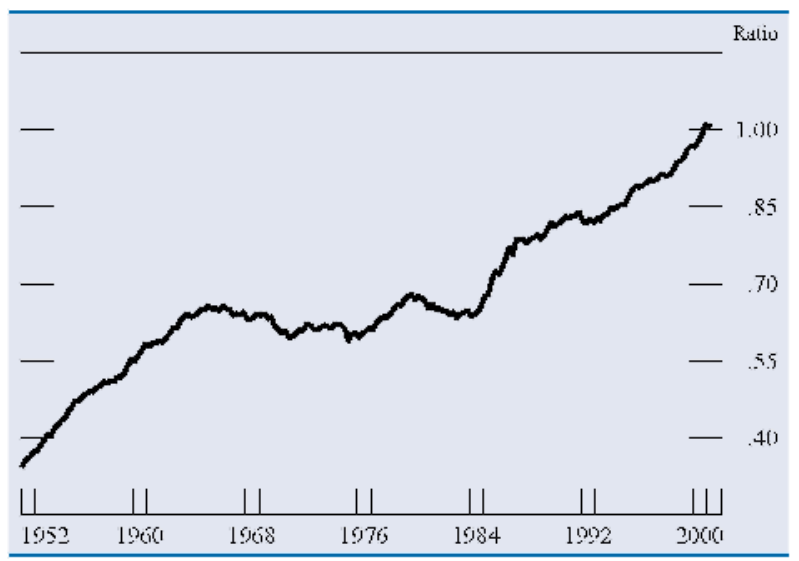

Note. Debt is debt outstanding at end of period, from the flow of funds accounts. Disposable personal income is after-tax income, from the national income and product accounts (Bureau of Economic Analysis, U.S. Department of Commerce)

increased from 63.9 percent of families in early 1991 to 67.5 percent in early 2001 .

The increased use of credit cards for transaction purposes appears to be an important factor underlying the growth of household sector debt over the current expansion. Credit card issuers indicate that in 1999 , each $\$ 1$ of debt was associated with just over $\$ 2.60$ in purchases, compared with about $\$ 1.90$ in purchases in 1990. Greater transaction use raises the average debt level in any given period, even if credit card balances are fully paid when due.

Also contributing to the sustained rise in debt has been the willingness of households to access the increased value of their assets through home mortgage loans. The rise in mortgage debt during the current economic expansion has been due in part to increased borrowing via loans for which accumulated home equity is used as collateral-home equity loans or refinancings accompanied by the conversion of some equity to cash.

Home equity borrowing was spurred initially by 1986 tax law changes and subsequently by promotion of home equity loan products. At first, the growth of home equity borrowing appeared mainly to change the composition of household sector debt: Mortgage debt, for which the interest continued to be taxdeductible, was substituted for consumer credit, for which, with the tax law changes, the interest was no longer tax-deductible. Over time, home equity borrowing became a more general means of obtaining funds. Such borrowing, which barely registered in the flow of funds accounts in the early $1990 \mathrm{~s}$, accounted for nearly one-fourth of home mortgage borrowing in 2000. The value of home equity loans outstanding at 
2. Value of home equity loans outstanding, 1990:Q4-2001:Q1

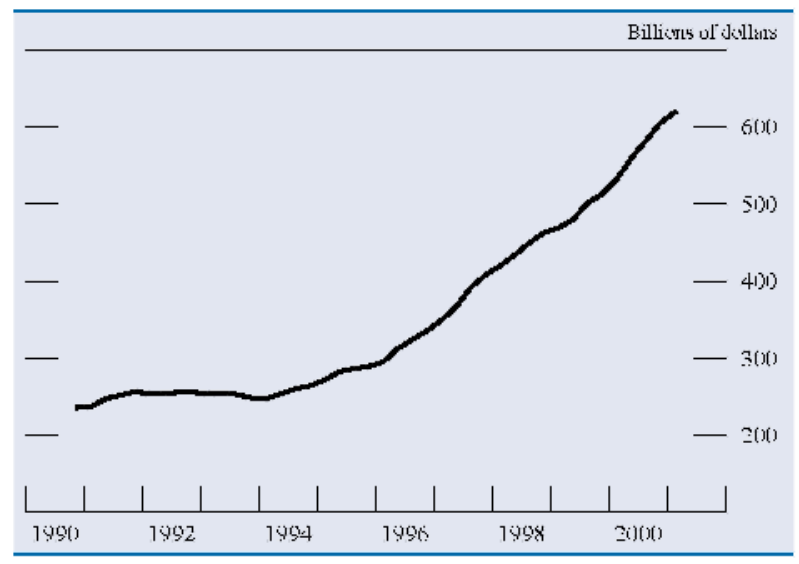

Note. Value of loans outstanding at end of period. Unless otherwise noted, data in this and subsequent charts are from the flow of funds accounts.

the end of the first quarter of 2001 was more than $\$ 619$ billion, up 142 percent since 1991 (chart 2).

Home mortgage refinancing has been spurred by successive declines in mortgage interest rates and also likely by declining costs to borrowers for the processing of such loans. Refinancing waves in 1992-93 and again in early and late 1998 were particularly pronounced. Because the flow of funds accounts record only net borrowing, they do not provide the detail necessary to estimate how much of recent mortgage borrowing can be attributed to cashout refinancing. Nonetheless, statistics on the number of refinanced loans and other data suggest that such activity has been significant in recent years.

Ultimately, whether the elevated level of household sector debt will lead to substantial financial distress will depend in large measure on whether employment and income conditions unfold in line with expectations and on the size and composition of household sector assets. The near-term burden of household debt is typically measured as scheduled principal and interest payments as a proportion of disposable personal income. Data in the accounts are combined with other available information to construct that measure. ${ }^{8}$ In early 2001 , the level of debt burden was close to the high reached in mid-1987 (chart 3), suggesting that strains could become evident if employment and income conditions deteriorate more than contemplated by borrowers and lenders when the loans were made.

8. The data and explanation of their construction are available on the Board's public web site at http://www.federalreserve.gov/releases/ housedebt/.
3. Scheduled principal and interest payments on household sector debt as a proportion of disposable personal income, 1980-2001:Q1

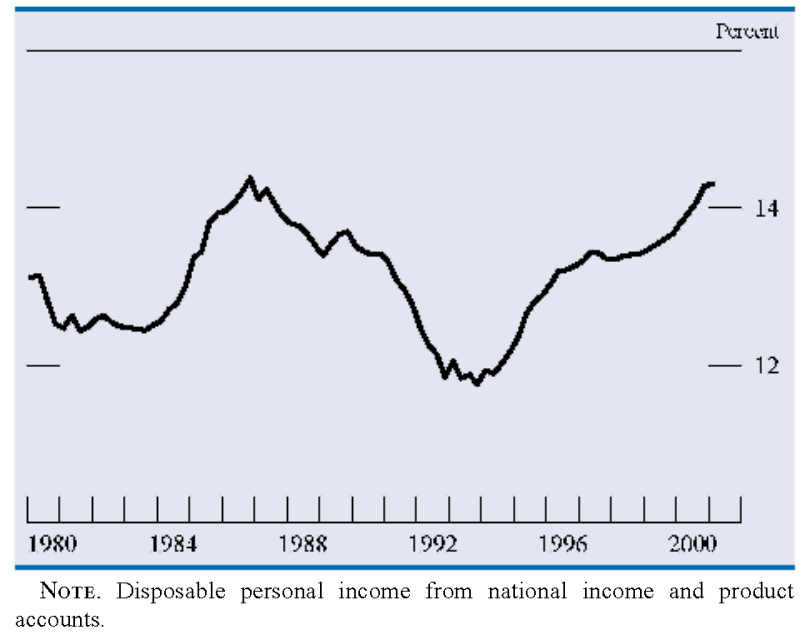

Assets

At the same time household sector debt and the burden of carrying that debt are elevated, the values of household sector assets are also unusually high. The flow of funds accounts contain considerable information on the size and composition of those assets, both tangible and financial. ${ }^{9}$

Household sector assets totaled $\$ 47.1$ trillion at the end of the first quarter of 2001. That is, households had more than six and one-half dollars in tangible and financial assets for each dollar of disposable income (chart 4), considerably more than the one dollar of debt for each dollar of disposable income noted in the preceding section. Moreover, the ratio of assets to income has increased markedly over the past ten years and, despite the recent decline in the value of some equity assets, is higher now than it was in the early 1990s or in any earlier period.

The composition of household assets has changed considerably over the past decade. The most dramatic

9. Tangible assets include owner-occupied homes and durable goods, such as automobiles. Financial assets include holdings of different types of deposit accounts, fixed income assets (such as government securities and corporate bonds), equity and mutual fund shares, and household pension reserves.

Information on household assets and liabilities is also available from the Federal Reserve Board's Survey of Consumer Finances. The two sources differ in several important respects. For example, the SCF data are based on a sample of households and are available only approximately every third year, whereas the household sector data in the flow of funds accounts are based on numerous macroeconomic sources and are published each quarter. Nonetheless, the two data sets are complementary in that they can be used together to examine household balance sheet changes and household sector behavior in considerable detail. 
4. Household sector assets relative to disposable personal income, 1952-2001:Q1



Note. Assets at end of period. Disposable personal income from the national income and product accounts.

change has been an increase in the proportion of assets in corporate equities, a development that has raised some concerns about households' exposure to equity price changes and the sustainability of the aggregate value of household assets. As recorded in the flow of funds accounts, at the beginning of the economic expansion, households held about 15 percent of their assets in equity; more recently, the proportion has been about 27 percent. At its peak, in early 2000 , the proportion was nearly 36 percent.

Not only do corporate equities now account for a larger share of household assets, but the distribution of those equities across instrument types has changed. Households retain equity either directly, in brokerage accounts, or indirectly, in mutual funds, life insurance annuities, bank personal trusts, and defined benefit and defined contribution pension plans. About 52 percent of the household sector's equity holdings were held indirectly at the end of 2000 , compared with 44 percent at the beginning of the economic expansion and less than 7 percent in the 1960s.

The distribution of their equity holdings across types of instruments may affect the way households view risk and the influence that changes in asset values have on their short-term saving and consumption. For instance, households may view their equity holdings in retirement instruments differently than their other equity holdings. The proportion of equity in retirement assets has risen of late. At the end of 2000 , the value of equity in pension plans was close to 33 percent of the total value of equity held by households, up from just under 30 percent in 1991 (table 3 ). In addition, the assets of individual retirement accounts (IRAs) also include equity shares. Adding a rough estimate of the value of equities held
3. Household sector holdings of equity in pension plans as a proportion of total equity holdings, year-end 1991 and 2000

Percent

\begin{tabular}{|c|c|c|}
\hline Item & 1991 & 2000 \\
\hline Total & 29.9 & 32.5 \\
\hline Private defined benefit plans & 10.6 & 7.5 \\
\hline Private defined contribution plans & 8.7 & 10.5 \\
\hline State and local government employee & & \\
\hline retirement funds & 8.7 & 9.2 \\
\hline Life insurance annuities & 1.9 & 5.3 \\
\hline $\begin{array}{l}\text { Memo: } \\
\text { Total including equity in IRAs }\end{array}$ & 35.5 & 40.5 \\
\hline
\end{tabular}

Note. Figures for defined benefit plans, defined contribution plans, and government employee retirement funds are derived from table B.100.e in the Z. 1 statistical release; figures for life insurance annuities and IRAs are based on data in tables L. 119 and L.225.i.

in IRAs to the value of equities in pension plans suggests that the retirement equity proportion of total equity was on the order of 41 percent in 2000 , compared with 36 percent in 1991.10

At the same time households' equity holdings have been increasing, their holdings of deposits and money market mutual fund shares as a proportion of their assets have been declining. Although the value of holdings in the latter categories increased from $\$ 3.3$ trillion at year-end 1991 to $\$ 4.7$ trillion in early 2001 , the value of such assets as a share of total household assets fell from $121 / 2$ percent to about 10 percent. Households continued to favor money market mutual funds over insured checkable deposits at banks and other depositories. The proportion of assets in credit market instruments-largely direct holdings of government securities and corporate bonds - declined from $6 \frac{1}{4}$ percent to less than $41 \%$ percent over the same period.

The aggregate balance sheet for the household sector has also recorded a substantial rise in the value of owner-occupied homes. Over the past ten years, the value of those homes has risen $\$ 4.6$ trillion, with the greatest part of the rise occurring in recent years. At the end of the first quarter of 2001, the market value of owner-occupied homes totaled more than $\$ 11.3$ trillion, compared with a market value of directly and indirectly held equities of $\$ 12.8$ trillion. Because households have used their homes as collateral for increasing their mortgage debt, the remaining equity in those homes has grown more gradually than has the total value. Home equity is currently around 55 percent of the value of owner-occupied real estate,

10. A recent addition to the accounts has been tables separately identifying flows into, and amounts outstanding of, individual retirement accounts. 
compared with 60 percent in the early 1990 s and as high as 70 percent in 1982.

Altogether, the broad perspective provided by the flow of funds accounts enables analyses of the buildup of household debt to take into account the growth of household assets, the development of loan products that reduce the cost of obtaining and carrying debt, and the change in the ways households are using debt. Specifically, the statistics in the accounts are used in econometric analyses of consumption, including analyses based on the FRB/US model developed at the Board." The data are also used to examine the process by which wealth and the composition of wealth affect household sector behavior. ${ }^{12}$ Thus, the flow of funds accounts are an essential tool for studying the effect of combined changes in assets and debt on economic growth.

\section{CORPORATE SECTOR FINANCES}

The flow of funds accounts are important in monitoring aggregate business borrowing trends and in studying the connection between corporations' financial condition and their nonfinancial economic activity, such as investment spending. The accounts record data for three domestic nonfinancial business sectors-unincorporated businesses, farms, and nonfarm corporations. The latter group has historically carried out the bulk of business economic activity and has generally accounted for more than two-thirds of business borrowing. The remainder of this section describes these nonfarm nonfinancial businesses, which, for simplicity, are referred to here as corporations or the corporate sector.

Borrowing by corporations has been substantial in recent years. ${ }^{12}$ Following a period early in the economic expansion during which their borrowing was

11. For an example of such use, see Flint Brayton, Eileen Mauskopf, David Reifschneider, Peter Tinsley, and John Williams, "The Role of Expectations in the FRB/US Macroeconomic Model," Federal Reserve Bulletin, vol. 83 (April 1997), pp. 227-45.

12. A summary of work on the wealth effect is provided in Morris A. Davis and Michael G. Palumbo, "A Primer" on the Economics and Time Series Econometrics of Wealth Effects," Finance and Economics Discussion Series 2001-9 (Federal Reserve Board, 2001). Recent work combining data from the flow of funds accounts and the Survey of Consumer Finances to examine the wealth effect is reported in Dean M. Maki and Michael G. Palumbo, "Disentangling the Wealth Effect: A Cohort Analysis of Household Saving in the 1990s," Finance and Economics Discussion Series 2001-21 (Federal Reserve Board, 2001).

13. Borrowed funds are by far the largest type of external funds available to corporations. An important additional source is foreign direct investment by foreign firms, which is discussed in Joseph E. Gagnon, "U.S. International Transactions in 2000," Federal Reserve Bulletin, vol. 87 (May 2001), pp. 283-94.
5. Corporate debt relative to the sector's output, 1952-2001:Q1

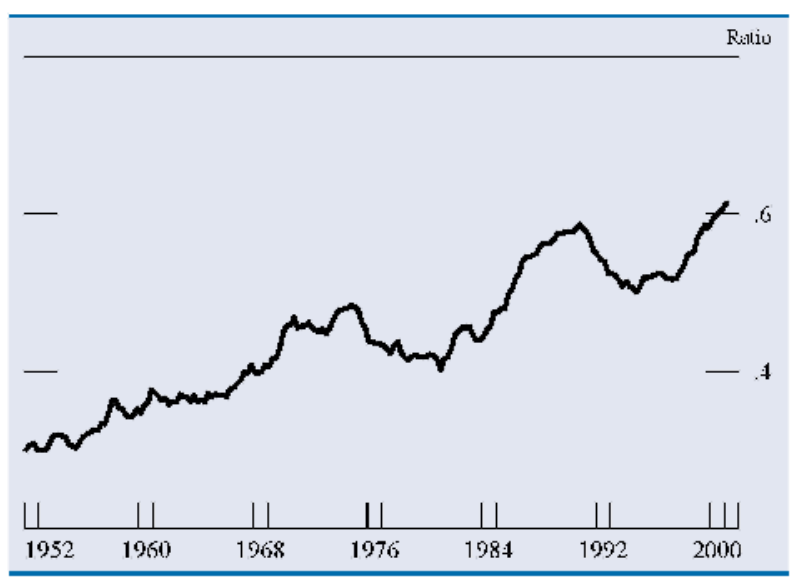

Note. Debt is debt outstanding at end of period. Sector output is gross business nonfarm product less housing, from the national income and product accounts. The corporate sector comprises domestic nonfarm nonfinancial corporations.

subdued, these businesses began to expand their debt rapidly. From 1995 through early 2001, corporate debt rose at an average annual rate of 9 percent, outstripping the $61 / 4$ percent average annual rise in the nominal value of the sector's gross domestic product (GDP).

Corporate debt as a proportion of sector GDP has increased over the postwar period, though by much less than household debt as a proportion of disposable personal income. And the ratio for corporate debt has varied considerably more over the period (chart 5). It jumped from just over 40 percent in the early 1980 s to nearly 60 percent in 1991, in part because borrowing was necessary to complete mergers and acquisitions and other types of corporate restructurings. The ratio subsequently dropped to 50 percent, but by early 2001 it had moved up again, to 61 percent.

Since 1995 , corporations have relied most heavily on the bond markets for external funds. At the end of the first quarter of this year, bond debt was about $\$ 21 / 2$ trillion, up from less than $\$ 11 / 2$ trillion at the beginning of 1995 (chart 6). Both investment-grade and below-investment-grade (junk bond) firms raised large sums over the period.

Borrowing from other sources has also been substantial, though less than borrowing via bonds. For example, over the period 1995 through the first quarter of 2001, borrowing from banks, saving institutions, and finance companies was only half as much as borrowing via bonds. Commercial paper debt climbed over most of the period, about doubling by mid-2000; more recently, such debt has contracted a bit because concerns about credit quality have 
6. Credit market debt owed by the corporate sector, 1995:Q1 and 2001:Q1

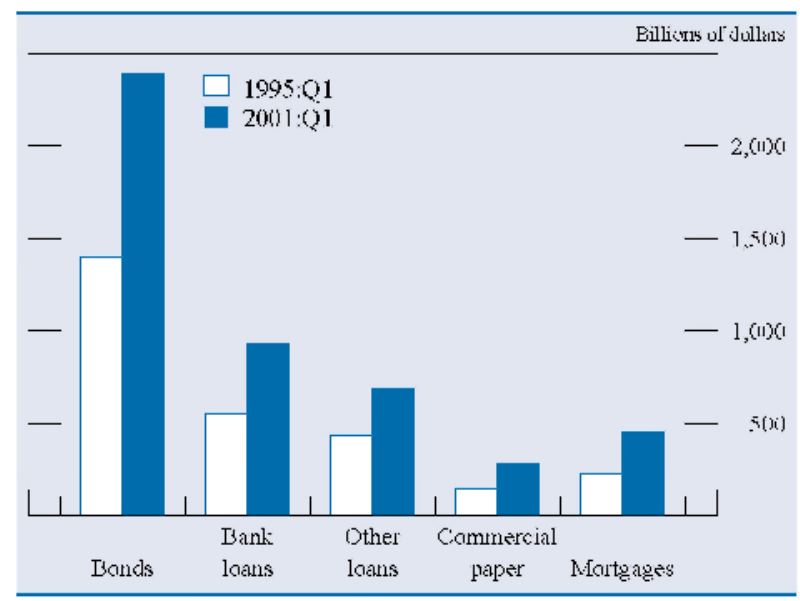

NoTE. Debt outstanding at end of quarter. Bonds include tax-exempt industrial revenue bonds. "Other loans" are (1) loans from savings institutions, finance companies, the federal government, the rest of the world (that is, foreign sources), and issuers of asset-backed securities and (2) acceptance liabilities to banks.

made investors wary of all but the most highly rated borrowers. Mortgage debt of corporations has increased significantly, although in percentage terms by less than in the $1980 \mathrm{~s}$, when overbuilding in the commercial and office building sectors became a serious problem for both lenders and investors.

Although borrowing from every source increased over the period 1995 through early 2001, there was considerable substitution among sources at times. One notable occasion began in 1998 and ran through late 1999-a time of significant turmoil in world capital markets associated with foreign currency crises, Russia's debt default, and losses by LongTerm Capital Management, a major U.S. hedge fund. In early 1998, net corporate bond issuance was particularly strong as firms took advantage of dips in long-term interest rates. Then, at the height of the uncertainty, net issuance plummeted, from an annual rate of $\$ 295$ billion to an annual rate of less than $\$ 110$ billion in the third quarter of 1998 (chart 7). Investors quickly turned away from the bond market, especially the more risky, lower-rated securities, and spreads between interest rates on riskier debt and investment-grade instruments soared. Firms that needed cash turned to prearranged credit lines at banks and other loan arrangements, and borrowing from banks and other short-term lenders rose. Subsequently, investor confidence in private securities returned, and corporate bond issuance again rose sharply. Loans, in contrast, fell off in mid-1999, in part reflecting paydowns of debt incurred during the earlier turmoil.
7. Selected borrowing by the corporate sector, 1998 and 1999

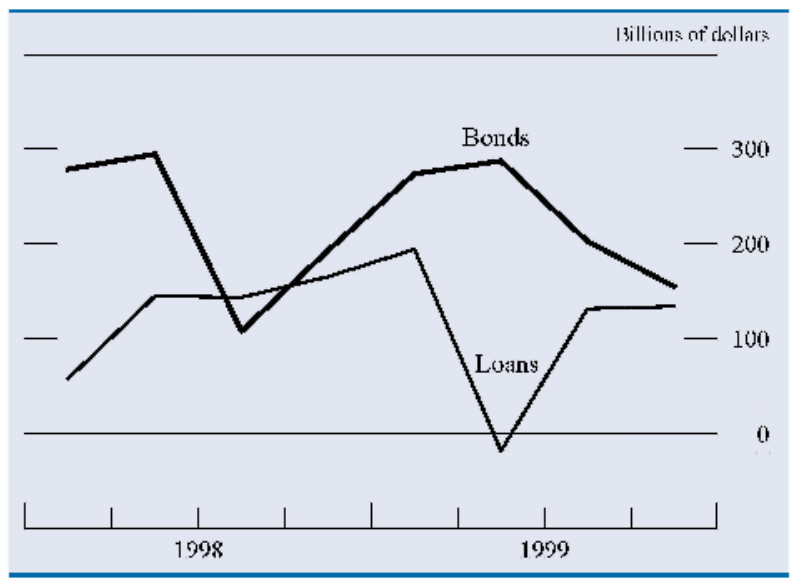

Note. Loans include both bank loans and "other loans" as defined in the note to chart 6. Quarterly data at seasonally adjusted annual rates.

Propelling the elevated volume of external funding by corporations have been an increase in capital expenditures, a high rate of equity retirements, and an accumulation of financial assets. Internal funds for financing these activities, although moving substantially higher over the current expansion, have increasingly fallen short of spending needs.

In nominal terms, annual capital expenditures rose 70 percent between 1995 and the end of 2000; the increase was particularly large because interest rates stayed low and the demand for productivityincreasing new technologies was intense. Over the period, the so-called financing gap-the difference between corporations' capital spending and their internal funds - nearly tripled, to $\$ 300$ billion. ${ }^{14}$ As a proportion of sector output, the corporate financing gap in 2000 was at its highest point in two decades (chart 8).

Corporations retired an extraordinary volume of equity over 1995-2000-on net, a whopping $\$ 819$ billion. Although many firms issued equity to finance capital investment and meet other corporate needs, for the sector as a whole, the value of shares issued was far surpassed by the value of shares retired in cash-financed mergers and through firms' own share repurchase programs. Between 1995 and year-end 2000, equity retirement associated with cash takeovers by domestic firms totaled $\$ 663$ billionand share repurchases totaled even more, $\$ 692$ bil-

14. For forecasting, looking at the financing gap in light of prospective credit developments is a way of assessing consistency between projected elements of nonfinancial activity and anticipated financial market conditions. 
8. Corporate financing gap as a proportion of the sector's output, 1985-2001:Q1

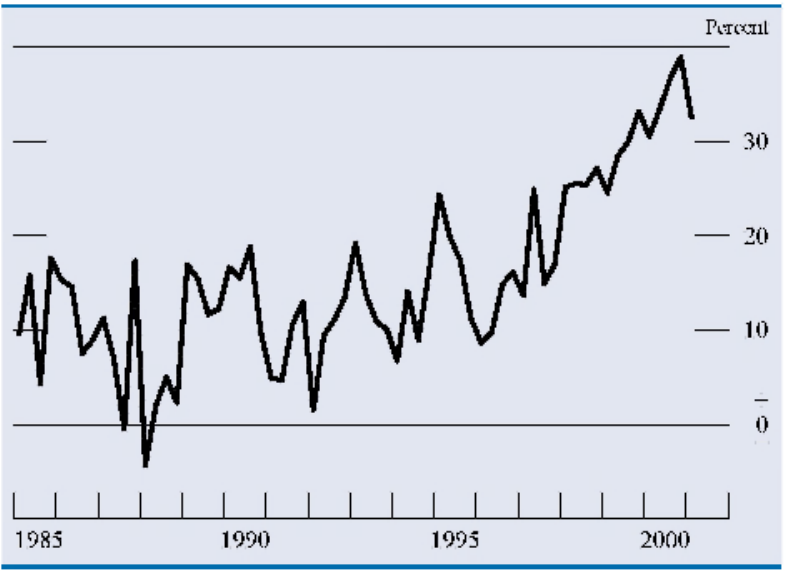

Note. The financing gap is the difference between the sector's capital expenditures and its internal funds (that is, its after-tax profits plus depreciation allowances).

lion. (For a broader discussion of accounting for net retirements of equity shares, see the box.)

Firms in the aggregate have used the favorable economic conditions since the mid-1990s to build their financial asset positions. Historically, corporations' net investment in financial assets has been small relative to their other uses of funds. They do, however, accumulate liquid assets for working capital and for transactions - and those assets have increasingly been moved into money market funds. Although the value of corporations' deposits in banks is still about double the value of their assets in money market funds, the latter has grown about twice as fast in recent years.

Borrowing by corporations has left a mark on corporate leverage as measured in the flow of funds

9. Corporate sector debt as a proportion of the sector's net worth, 1952-2001:Q1

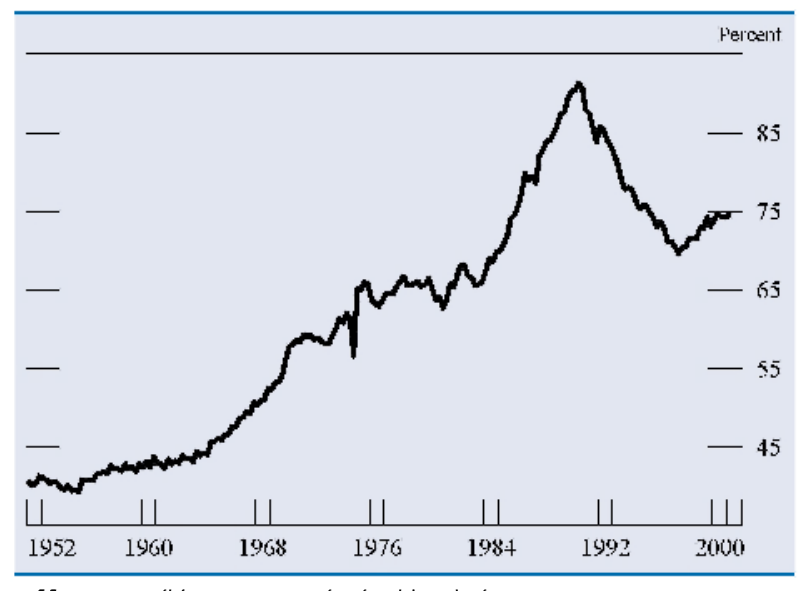

Note. Tangible assets are valued at historical cost.
10. Net interest payments by corporations as a proportion of the corporate sector's cash flow, 1952-2001:Q1

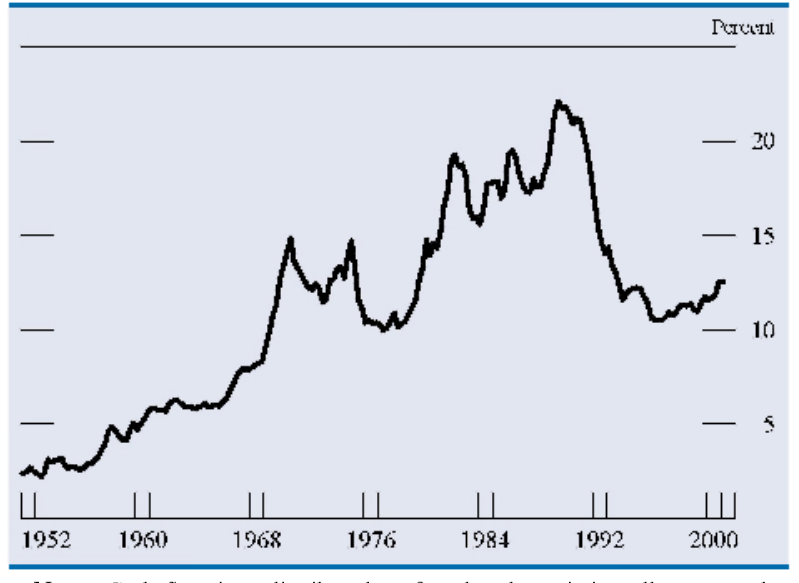

Note. Cash flow is undistributed profits plus depreciation allowances plus net interest.

SoURCE. National income and product accounts.

accounts. Debt relative to net worth declined sharply early in the 1990s (chart 9). Since late 1997, the leverage ratio has retraced some of that decline, and at the end of the first quarter of 2001, it was about one-quarter of the way to its most recent peak in 1990. Debt measured against the market value of corporations (that is, against the value of corporate equity outstanding) has turned up only recently, a development reflecting the sharp run-up and subsequent decline in stock prices.

Some analysts have been wary of the buildup of corporate debt and the rise in leverage ratios. However, the implications of these changes for future economic developments are by no means clear. At the same time businesses were adding to their debt, they were refunding their older, higher cost obligations with lower cost bonds and loans and were reducing their debt burden in much the same way households refinanced their debt. Net interest payments by firms relative to their cash flow dropped sharply, from more than 20 percent before the 1990-91 recession to around 10 percent in 1995. Even with the additional debt taken on since then, the ratio has inched up to only about 12 percent (chart 10).

Despite the large volume of debt issued, the composition of corporations' liabilities is not much different now than it was in 1995. Firms have not markedly increased their reliance on short- and intermediateterm debt, for which interest rates could change rapidly. Statistics in the flow of funds accounts show that bond debt at the end of the first quarter of 2001 was about 49 percent of total corporate debt outstanding, and bank loans 20 percent; the remaining debt was 


\section{Accounting for Net Retirements of Equity Shares}

The large volume of net retirements of equity shares over $1995-2000$ is a source of frequent misunderstanding because of the way equity transactions are treated in the flow of funds accounts. The accounts show only net equity issuance - the difference between gross equity issuance, a positive source of funds to the corporate sectors, and equity retirements, a negative source of funds to the corporate sectors.

For domestic firms, both nonfinancial and financial, equity retirements over 1995-2000 exceeded gross issuance; for foreign firms (the "rest of the world" sector), gross issuance of equity in the United States exceeded retirements, partly offsetting net retirements by domestic firms (table). Overall, net issuance of equity in the United States over the period was negative; that is, share retirements for the economy as a whole exceeded share issuance.

By definition, net purchases of equity (a use of funds for all except the corporate sectors) must equal net issuance of equity. Because total net issuance by corporations was negative over the period, total net purchases for the remaining sectors was negative

Net issuance and net purchases of equity shares, 1995-2000 Billions of dollars

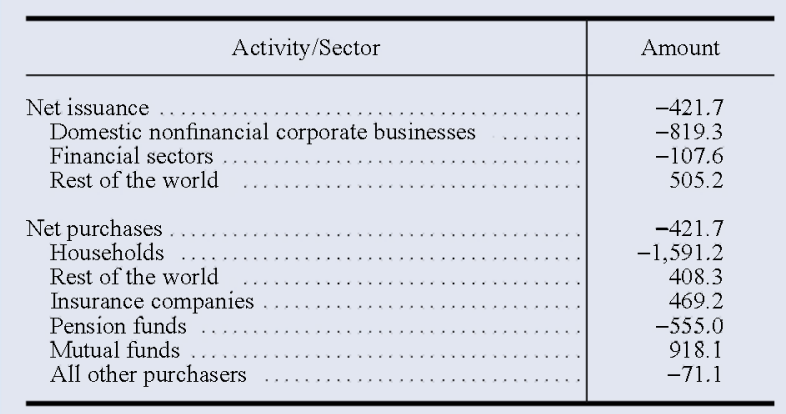

Which sectors sold shares to corporations on net? Not mutual funds, which have been significant net purchasers of equity in recent years; over 1995-2000, their purchases exceeded their sales by more than $\$ 918$ billion. And not foreigners and insurance companies, which were also large net purchasers over the period. It was pension funds and households that were net sellers of shares to corporations over 1995-2000. Households, which in terms of value outstanding hold about 45 percent of equity, were the largest net sellers of equity, selling $\$ 1.6$ trillion on net over the period.

Figures showing that households were net sellers of (directly held) equities may be unexpected, as the value of the household sector's holdings of equity assets has increased in most recent years. The explanation is that the capital gains on the shares that households continued to hold exceeded net sales by households. The following example shows how either positive or negative net purchases can be associated with increases in the value of assets. Suppose that over a twelve-month period, net purchases by the household sector were zero because households traded only among themselves, making the total value of sales equal to the total value of purchases. If over that period the price of equities for the economy as a whole, as measured by a broad stock market index, had risen, the total value of holdings would show an increase over the period even though net purchases were zero. Similarly, if the stock market index had declined, the total value of holdings by households would show a decrease. The value outstanding is the sum of net purchases and the change in price of equity (capital gain or loss). The price changes for equity have typically been the main determinant of the change in the value of holdings over a period, despite large negative net purchases by the household sector. mainly loans from other sources, commercial paper, and mortgages. The proportion that was bond debt was only a little higher than in 1995 or, even further back, in 1991 at the start of the current expansion.

\section{CONCLUSION}

The flow of funds accounts have been useful in observing key economic trends and studying the relationships between real and financial developments. This article has summarized recent trends for households and domestic nonfarm nonfinancial corpora- tions. The accounts encompass other important sectors of the economy, however, including financial intermediaries and governments, and contain considerably more sectoral detail than can be summarized in a limited space. Ongoing analysis using the accounts will help expand our knowledge of macroeconomic and financial relationships and the determinants of household and business behavior. A key challenge will be ensuring that the accounts continue to capture the structure of the financial system and provide the level of detail useful for policy and behavioral analyses. 